\title{
Faecal contamination of echinoderms: first report of heavy Escherichia coli loading of sea urchins from a natural growing area
}

\author{
Bouchoucha Marc ${ }^{1,{ }^{*}}$, Piquet Jean-Come ${ }^{2}$, Chavanon Fabienne ${ }^{1}$, Dufresne C. ${ }^{3}$, Le Guyader Soizick ${ }^{2}$ \\ ${ }^{1}$ Laboratoire Environnement Ressources Provence Azur Corse; Ifremer; La Seyne-sur-Mer France \\ 2 Laboratoire de Microbiologie, LSEM-SG2M; Ifremer; Nantes France \\ ${ }^{3}$ IRSN; La Seyne-sur-Mer France \\ *Corresponding author : Marc Bouchoucha, email address : $\underline{\text { marc.bouchoucha@ifremer.fr }}$
}

\begin{abstract}
:
Although little evidence existed to support that view, European countries and in particular France, have regarded echinoderms, including sea urchins, as low risk in terms of feacal contamination. It is hypothesized that the sea urchins mode of feeding, which is based on grazing and differs from bivalve molluscs, would prevent it from concentrating high levels of Escherichia coli. Here, we monitored E. coli levels in sea urchins (Paracentrotus lividus) and in filter-feeder mussels (Mytillus galloprovincialis), collected concurrently from the same natural area over a 1-year period to verify this assumption. Sea urchins were collected on the seafloor, whereas mussels were collected from the water column at a depth of $4 \mathrm{~m}$. Our results showed heavy bacterial loading of sea urchins in a natural growing environment. Moreover, we highlighted that E. coli contamination of sea urchins could, in certain conditions, be higher than those detected in filter-feeding mussels collected at the same location. Finally, the results showed a significant correlation between rainfall and $E$. coli concentrations in sea urchins, suggesting that the bacterial safety of sea urchin could be linked to the quality of the surrounding water.
\end{abstract}

\section{Significance and Impact of the Study}

The European regulation requires competent authorities to monitor the sanitary status of shellfish, including live echinoderms, through faecal indicator organisms. In the French Mediterranean, sea urchin production is significant. Until now, as no data showed significant $E$. coli contamination levels, no monitoring programs focused on this species. This study demonstrates that sea urchins are more vulnerable to faecal contamination than previously hypothesized, especially during heavy rainfall. In consequence, the European authority general approach to microbiological management of shellfish should be applied to sea urchins. 
Keywords : E. coli, fecal contamination, mussel, Sea urchin, shellfish monitoring program

\section{Introduction}

The global demand for seafood has increased dramatically over the last few decades, as it has become more widely recognized as a relatively cheap and nutritional food source (Gjedrem et al. 2012). However, in coastal environments through filter feeding and respiration, shellfish can bioaccumulate pathogenic micro-organisms associated with human and animal fecal contamination originating from the watershed (Spacie et al. 1995; Riou et al. 2007; Iwamoto et al. 2010; Maalouf et al. 2010). Thus, the increase in shellfish consumption is accompanied by an increase in shellfish 
vectored illness in humans, with many major outbreaks occurring over the last century (Potasman et al. 2002; Hall et al. 2012; Bellou et al. 2013; Painter et al. 2013). As a consequence, many developed countries set up legislation to regulate all aspects of the shellfish industry. In the European Union, shellfish safety is currently governed under regulation (EC) No 854/2004 (Anon. 2004), which stipulates that the sanitary status of shellfish must be monitored through fecal indicator organisms, specifically Escherichia coli. Indeed, the use of E. coli as an indicator of shellfish microbiological safety has been shown to enhance the quality of shellfish put on the market and a decrease in bacterial illness outbreaks was observed (Fewtrell et al. 2001). The legislation is applied to live bivalve molluscs, which are filter-feeding organisms, and to live echinoderms, live tunicates and live marine gastropods. The amount of $E$. coli present in these shellfish products determines the postharvest treatment that is required prior to marketing, but may also result in changes in management practice, or temporary closure of the harvesting areas. Up until now, microbiological data has only been generated through the routine monitoring programs for European bivalve shellfish production areas, and the levels of bacterial contamination in echinoderms, tunicates and marine gastropods was poorly documented.

In France there are no reliable data on the production volume of sea urchins, gastropods or tunicates, however anecdotal information suggests that production may be significant, with estimates for the French Mediterranean of sea urchin production exceeding 50 tonnes per year. The purple sea urchin, Paracentrotus lividus (Lamarck, 1816), is a grazer-feeding echinoderm which is found in the Mediterranean and North-Eastern Atlantic in rocky intertidal and shallow subtidal habitats and in seagrass meadows (Boudouresque and Verlaque 2001). The species is mainly produced and consumed in France, Spain and Italy (Le Direach 1987; Guidetti et al. 2004; Gianguzza et al. 2006; Fernández-Boán et al. 2013), but is also produced in other countries (Barnes and Crook 2001; Bertocci et al. 2014). Furthermore, because they are frequently found in shallow waters, purple sea urchins are also subjected to recreational fishing (Gianguzza et al. 2006; Pais et al. 2007).

This article is protected by copyright. All rights reserved. 
The gonads of sea urchins are generally consumed raw with no post harvest control steps, thus increasing the associated sanitary risk. To our knowledge, there have been very few studies on the contamination of sea urchins with E. coli, one such study concluded that the risk of bacterial contamination of sea urchins is greatly reduced in comparison with the surrounding seawater and, that $P$. lividus is much less sensitive to bacterial contamination than filter-feeding bivalves such as mussels (Stabili et al. 2013). It was hypothesized that the sea urchins mode of feeding, which is based on grazing and differs from bivalve molluscs, which are filter-feeders, would prevent it from concentrating high levels of E. coli. Given the foregoing, the objective of this study was to evaluate the relative ability of the sea urchin to accumulate $E$. coli in comparison to filter feeding mussels in the natural environment.

To fulfill this aim, we monitored $E$. coli levels in sea urchins ( $P$. lividus) and in filter-feeder mussels (Mytillus galloprovincialis), collected at the same time from the same area close to a small tributary each fortnight during one year. We also explored the potential effect of heavy rainfalls.

Results and discussion

To date there have been very few studies that have investigated $E$. coli contamination in sea urchins in a natural growing environment. To our knowledge, this is the first study that has investigated this issue thoroughly, by carrying out a one-year monitoring program, exploring the potential effect of heavy rainfall and, simultaneously comparing contamination in both a filter-feeding organism (mussels) and a grazing organism (sea urchins).

A total of 27 mussel samples and 27 sea urchin samples were collected and analyzed, 21 for the regular monitoring (each fortnights) and 6 supplementary following heavy rainfalls (> 25mm in $96 \mathrm{~h}$ ) (Fig. 1). For the regular monitoring, the maximum E. coli concentrations in mussels and sea urchins were respectively 1,300 and 9,200 E. coli MPN $100 \mathrm{~g}^{-1}$ FIL (Flesh and Intervalvular Liquor). Less than

This article is protected by copyright. All rights reserved. 
$24 \%$ of samples exceeded 230 E. coli MPN $100 \mathrm{~g}^{-1} \mathrm{FIL}$, which corresponds to the limit above which shellfish must be depurated before being commercialized (Anon. 2004) (Table 1). Following rainfall periods, the maximum value of $E$. coli in mussels was 2,400 E. coli MPN $100 \mathrm{~g}^{-1} \mathrm{FIL}$, and reached 92,000 E. coli MPN $100 \mathrm{~g}^{-1} \mathrm{FIL}$ in sea urchins. Thus, it seems probable that the risk of accumulation of fecal indicator bacteria in sea urchins, which are a grazing marine organism, may be higher than previously considered. While contamination of $P$. lividus by $E$. coli had already been reported in controlled conditions (Stabili et al. 2013), this is the first demonstration of heavy bacterial loading of sea urchins in the natural environment. However, although we demonstrated that the risk of accumulation of micro-organisms related to fecal contamination in sea urchins should not be neglected, no foodborne-disease outbreak associated to their consumption was ever reported to our knowledge. The main reasons for the lack of recorded outbreaks could be the relative low consumption of sea urchins compared to other shellfish products, the number of unreported cases that may be relevant, the way of consumption of sea urchins (only gonads are eaten) or the fact that sanitary risk concerns only a limited number of their growing areas. Further research should be conducted to investigate these hypotheses.

Moreover, while the $E$. coli concentrations were not statistically different between species, when considering samples collected post-heavy rainfall $(p=0.474)$, during dry periods $(p=0.620)$, or over the entire study period $(p=0.997), E$. coli concentrations were higher in sea urchins than in mussels for $48 \%$ of the sampling occasions, equal for $15 \%$, and lower for $37 \%$. Considering only the results obtained after heavy rainfall, higher E. coli concentrations were detected in sea urchins than in mussels for $67 \%$ of the sampling occasions. Thus, it was noted that $E$. coli contamination of sea urchins could, in certain conditions, be higher than those detected in filter-feeding mussels collected concurrently from the same area. It is clear that grazing marine organisms can accumulate nonindigenous pathogenic microorganisms as a consequence of their feeding activity (Stabili et al. 2013). We hypothesize that fecal bacteria could be deposited on algae and thus be accumulated by sea urchins through their normal feeding activity. Indeed, it is well known that a proportion of micro-

This article is protected by copyright. All rights reserved. 
organisms that are discharged into the marine environment settle onto the sediment layer, and higher concentrations of fecal indicator bacteria have been detected in the sediments compared to the surrounding waters (Chan et al. 1979; LaBelle et al. 1980; Martinez-Manzanares et al. 1992; Miura et al. 2009). In our study, sea urchins were collected on the seafloor (8m), whereas mussels were collected from the water column at a depth of $4 m$ - the depth at which they are generally harvested in the Mediterranean. Although not directly measured during our study, differences in $E$. coli concentration in the immediate environment (sediment vs. water column) could account for the difference in E. coli concentrations in sea urchins and mussels observed in this study.

Finally, there was a significant correlation between precipitation levels and $E$. coli concentrations in sea urchins or mussels (respectively, $\rho=0.498(p=0.008)$ and $\rho=0.531,(p=0.004))$. This result was not surprising. It is well known that the potential for contamination of coastal waters by bacterial pathogens like $E$. coli increases during short-term heavy rainfall events, which can lead to sewage treatment facilities exceeding their capacity and the release of untreated sewage into the sea, especially in the vicinity of small tributaries (Griffin et al. 2003; Riou et al. 2007; Maalouf et al. 2010). These short-term water contamination events can explain high E. coli levels in shellfish. However, the $E$. coli concentration in sea urchins in this study reached 9,200 MPN $100 \mathrm{~g}^{-1} \mathrm{FIL}$ during a dry period, this result was unexpected given the rainfall level was $<3 \mathrm{~mm}$ in $96 \mathrm{~h}$ and should be explored.

In conclusion, we demonstrated that in an area close to a small tributary, sea urchins are vulnerable to fecal contamination, especially during periods of high rainfall. Numerous studies have showed that the bacterial contamination of filter-feeding bivalves is directly related to the quality of the water in which they grow (see Oliveira et al. 2011 for review). Our study suggests for the first time that this is also the case for sea urchins. However, only the gonad portion of the urchin is consumed, thus the next step may be to evaluate bacterial distribution within the different organs of the urchin to determine if the gonad concentrates high levels of fecal bacteria, and potentially other pathogens such as human enteric viruses.

This article is protected by copyright. All rights reserved. 
Materials and methods

Study area

The study area is located in the South-East of France on the French Riviera rocky coast, at the outlet of a small river that flows through the city of Toulon (Fig. 2). Its watershed is about $70 \mathrm{~km}^{2}$ and mainly consists of urban areas. The Mediterranean climate is characterized by long dry periods with short but intense seasonal rainfall, given this climate the discharge from this river undergoes fast changes as a function of the weather conditions. Given these conditions, in order to prevent floods in the city of Toulon, a cofferdam was constructed upstream to redirect the river water directly to the sea without any treatment. This second output discharges into the rocky bottom of the sea where there is a natural growing area for the sea urchin, $P$. lividus (mean density $=5.91 \pm 3.57$ individuals $\mathrm{m}^{2}$ - data collected for this study). The study area was positioned directly in front of this second outlet, about $50 \mathrm{~m}$ off the coastline, at a depth between 4 and $10 \mathrm{~m}$.

Sampling protocol

The study was conducted between October 2012 and October 2013. Mussels, M. galloprovincialis, were not naturally present in the study area. Thus, we transplanted individuals from a different harvesting area (class B under EC No 854/2004 (Anon. 2004)) located 6 km away in Lazaret Bay, one month before the study started. A homogenous batch of mussels, which were each $50 \pm 5 \mathrm{~mm}$ in length, was separated into five $2.5 \mathrm{~kg}$ sub-samples and stored in pouches mounted on PVC tubing. The pouches containing the mussels were immersed in the study area above the sea urchins, which were on the bottom of the sea at a depth of $8 \mathrm{~m}$. The pouches were weighed down by means of a ballast weighing about $30 \mathrm{~kg}$, and maintained at a depth of $4 \mathrm{~m}$ by the means of a 11 litre buoy (Andral et al. 2004).

This article is protected by copyright. All rights reserved. 
Each fortnight 30 mussels and 20 sea urchins were sampled from the study area by scuba divers.

Supplementary samples were collected following heavy rainfall (> $25 \mathrm{~mm}$ in 96h, precipitation levels provided daily by Météofance, French National Meteorological Agency). Samples were rinsed in seawater in the field and kept cool (between 2 and $15^{\circ} \mathrm{C}$ ) during transportation. All the samples were transported to the laboratory in less than 24 hours.

Analyses

Bacterial analyses were conducted in an official control laboratory that was accredited (ISO 17025) for the enumeration of $E$. coli in shellfish. The enumeration of $E$. coli was performed by a five-tube, three-dilution most probable number (MPN) method using 5-bromo-4-chloro-3-indolyl- $\beta$-Dglucuronide following the ISO TS 16649-3 reference method (Anon. 2004).

For each sample, individual shellfish were rinsed under cold running potable tap water. The 20 sea urchins and 30 mussels collected were opened using sterile scissors and a shucking knife. The flesh and liquor were emptied from the shell of each animal into a sterile blender to achieve a minimum weight of $75 \mathrm{~g}$. The flesh and liquor were diluted 1:3 with tryptone salt water and homogenized in the blender for 1 minute. The first stage of the $E$. coli method was a resuscitation step requiring inoculation of minerals modified glutamate broth (MMGB) with a series of diluted shellfish homogenates and incubation at $37 \pm 1^{\circ} \mathrm{C}$ for $24 \pm 2$ hours. The presence of $E$. coli was confirmed by sub-culturing acid producing tubes onto agar containing 5-bromo-4-chloro-3-indolyl- $\beta$-D glucuronide and detecting $\beta$-glucuronidase activity (TBGA/TBX plates), and incubating the agar plates at $44 \pm 1^{\circ} \mathrm{C}$ for $22 \pm 2$ hours. After the incubation period the TBGA/TBX plates were examined for the presence of blue-green colonies. The results were recorded as positive for any shade of dark or light blue or bluegreen colonies, negative for colonies of any other colour; or 'no growth'. For each dilution, the number of positive TBGA/TBX plates gave a three figure combination number, which is used to calculate the MPN. The MPN results were determined using an Excel spreadsheet MPN calculator

This article is protected by copyright. All rights reserved. 
(http://standards.iso.org/iso7218/). Only values determined from combinations that give a category 1 or 2 profile were recorded.

Statistical analysis

Univariate PERMANOVA (Anderson 2001) were run to test: (1) inter-specific differences in E. coli contamination; and (2) species-specific differences in E. coli concentration between regular monitoring and rainfall periods ( $>25 \mathrm{~mm}$ in $96 \mathrm{~h}$ ). Concentration in E. coli were $\log (\mathrm{X}+1)$ transformed prior to the generation of Euclidean distance similarity matrixes. Since heavy rainfalls can affect contamination levels differently between species, inter-specific differences were also checked for the regular monitoring and during rainfall periods separately. P-values were calculated by 9999 random permutations of residuals under a reduced model and Type III sum of square (Anderson 2001). Significance was set at $\alpha=0.05$. All of these analyses were performed using the PRIMER 6 software and the PERMANOVA add-on (Clarke and Warwick 2001). Finally, the relationship between the cumulative rainfall level after $96 \mathrm{~h}$ and $E$. coli concentration in shellfish was investigated separately for each species by calculation of Spearman's rank correlation coefficients (hereafter $\rho$ ). Significance was also set at $\alpha=0.05$.

\section{Acknowledgements}

This work was supported by the French Government (DGAL; grant 2013-12/1219993/NYF). We thank Catherine McLeod (Seafood Safety Assessment) for critical review of the manuscript.

Conflict of Interest

No conflict of interest declared.

This article is protected by copyright. All rights reserved. 
References

Anderson, J.M. (2001) Permutation tests for univariate or multivariate analysis of variance and regression. Can J Fish Aquat Sci 58, 626-639

Andral, B., Stanisiere, J.Y., Sauzade, D., Damier, E., Thebault, H., Galgani, F. and Boissery, P. (2004)

Monitoring chemical contamination levels in the Mediterranean based on the use of mussel caging. Mar Pollut Bull 49, 704-712

Anon. (2004) Regulation EC/854/2004 of the European parliament and of the council of 29th April 2004 laying down specific rules for the organisation of official controls on products of animal origin intended for human consumption. In Official Journal of the European Union, Series L. pp.83-127.

Barnes, D.K. and Crook, A.C. (2001) Implications of temporal and spatial variability in Paracentrotus lividus populations to the associated commercial coastal fishery. In Coastal Shellfish-A Sustainable Resource. pp.95-102: Springer.

Bellou, M., Kokkinos, P. and Vantarakis, A. (2013) Shellfish-Borne Viral Outbreaks: A Systematic Review. Food Environ Virol 5, 13-23

Bertocci, I., Dominguez, R., Machado, I., Freitas, C., Godino, J.D., Sousa-Pinto, I., Gonçalves, M. and Gaspar, M. (2014) Multiple effects of harvesting on populations of the purple sea urchin Paracentrotus lividus in north Portugal. Fish Res 150, 60-65

Boudouresque, C.F. and Verlaque, M. (2001) Ecology of Paracentrotus lividus. Dev Aquacult Fish Sci 32, 177-216

Chan, K.-Y., Wong, S.H. and Mak, C.Y. (1979) Effects of bottom sediments on the survival of Enterobacter aerogenes in seawater. Mar Pollut Bull 10, 205-210

Clarke, K.R. and Warwick, R.M. (2001) Change in marine communities: an approach to statistical analysis and interpretation: PRIMER-E Limited Plymouth, UK.

Fernández-Boán, M., Freire, J., Parma, A.M., Fernández, L. and Orensanz, J.M. (2013) Monitoring the fishing process in the sea urchin diving fishery of Galicia. In ICES Journal of Marine Science: Journal du Conseil.

Fewtrell, L., Bartram, J. and Organization, W.H. (2001) Water quality: Guidelines, standards, and health: Assessment of risk and risk management for water-related infectious disease: IWA Publishing. Gianguzza, P., Chiantore, M., Bonaviri, C., Cattaneo-Vietti, R., Vielmini, I. and Riggio, S. (2006) The effects of recreational Paracentrotus lividus fishing on distribution patterns of sea urchins at Ustica Island MPA (Western Mediterranean, Italy). Fish Res 81, 37-44

Gjedrem, T., Robinson, N. and Rye, M. (2012) The importance of selective breeding in aquaculture to meet future demands for animal protein: A review. Aquaculture 350-353, 117-129

Griffin, D.W., Donaldson, K.A., Paul, J.H. and Rose, J.B. (2003) Pathogenic human viruses in coastal waters. Clin Microbiol Rev 16, 129-143

Guidetti, P., Terlizzi, A. and Boero, F. (2004) Effects of the edible sea urchin, Paracentrotus lividus, fishery along the Apulian rocky coast (SE Italy, Mediterranean Sea). Fish Res 66, 287-297

Hall, A.J., Eisenbart, V.G., Etingue, A.L., Gould, L.H., Lopman, B.A. and Parashar, U.D. (2012)

Epidemiology of Foodborne Norovirus Outbreaks, United States, 2001-2008. Emerg Infect Dis 18, 1566-1573

Iwamoto, M., Ayers, T., Mahon, B.E. and Swerdlow, D.L. (2010) Epidemiology of Seafood-Associated Infections in the United States. Clin Microbiol Rev 23, 399-411

LaBelle, R.L., Gerba, C.P., Goyal, S.M., Melnick, J.L., Cech, I. and Bogdan, G.F. (1980) Relationships Between Environmental Factors, Bacterial Indicators, and the Occurrence of Enteric Viruses in Estuarine Sediments. Appl Environ Microbiol 39, 588-596

Le Direach, J. (1987) La pêche des oursins en Méditerranée: historique, techniques, législation, production. In Colloque international sur Paracentrotus lividus et les oursins comestibles GIS Posidonie Publ, Marseille. pp.335-362.

Maalouf, H., Pommepuy, M. and Le Guyader, F. (2010) Environmental Conditions Leading to Shellfish Contamination and Related Outbreaks. Food Environ Virol 2, 136-145

This article is protected by copyright. All rights reserved. 
Martinez-Manzanares, E., Moriñigo, M.A., Castro, D., Balebona, M.C., Sanchez, J.M. and Borrego, J.J. (1992) Influence of the faecal pollution of marine sediments on the microbial content of shellfish. Mar Pollut Bull 24, 342-349

Miura, T., Masago, Y., Chan, Y.-M., Imai, T. and Omura, T. (2009) Detection of bacteria and enteric viruses from river and estuarine sediment. J Water Environ Technol 7, 307-316

Oliveira, J., Cunha, A., Castilho, F., Romalde, J.L. and Pereira, M.J. (2011) Microbial contamination and purification of bivalve shellfish: Crucial aspects in monitoring and future perspectives - A minireview. Food Control 22, 805-816

Painter, J.A., Hoekstra, R.M., Ayers, T., Tauxe, R.V., Braden, C.R., Angulo, F.J. and Griffin, P.M. (2013) Attribution of Foodborne Illnesses, Hospitalizations, and Deaths to Food Commodities by using Outbreak Data, United States, 1998-2008. Emerg Infect Dis 19, 407-415

Pais, A., Chessa, L.A., Serra, S., Ruiu, A., Meloni, G. and Donno, Y. (2007) The impact of commercial and recreational harvesting for Paracentrotus lividus on shallow rocky reef sea urchin communities in North-western Sardinia, Italy. Estuar Coast Shelf Sci 73, 589-597

Potasman, I., Paz, A. and Odeh, M. (2002) Infectious Outbreaks Associated with Bivalve Shellfish Consumption: A Worldwide Perspective. Clin Infect Dis 35, 921-928

Riou, P., Le Saux, J.-C., Dumas, F., Caprais, M.-P., Le Guyader, S. and Pommepuy, M. (2007) Microbial impact of small tributaries on water and shellfish quality in shallow coastal areas. Water Res 41, 2774-2786

Spacie, A., McCarty, L. and Rand, G. (1995) Bioaccumulation and bioavailability in multiphase systems. In Fundamentals of Aquatic Toxicology Taylor \& Francis, Washington, US. pp.493-521. Stabili, L., Terlizzi, A. and Cavallo, R.A. (2013) Sewage-exposed marine invertebrates: survival rates and microbiological accumulation. Envion Sci Pollut R 20, 1606-1616

List of figures

Figure 1: Comparison of E. coli concentrations in mussels and sea urchins using a Most Probable Number (MPN) technique and the relationship to the cumulative rainfall over $96 \mathrm{~h}$ as determined from daily data from Météofrance (see text for details).

Figure 2: Map of the sampling area

Table 1: Number and percentage of mussel and sea urchin samples containing various concentrations of $E$. coli when classified according to regulation (EC) No 854/2004 (Anon. 2004). The descriptive statistics are provided for samples that were routinely collected, collected during rainfall events, and for the whole dataset. Maximum E. coli concentrations (Max) and geometric means are also reported.

This article is protected by copyright. All rights reserved. 
Figure 1: Comparison of E. coli concentrations in mussels and sea urchins using a Most Probable Number (MPN) technique and the relationship to the cumulative rainfall over $96 \mathrm{~h}$ as determined from daily data from Météofrance (see text for details).

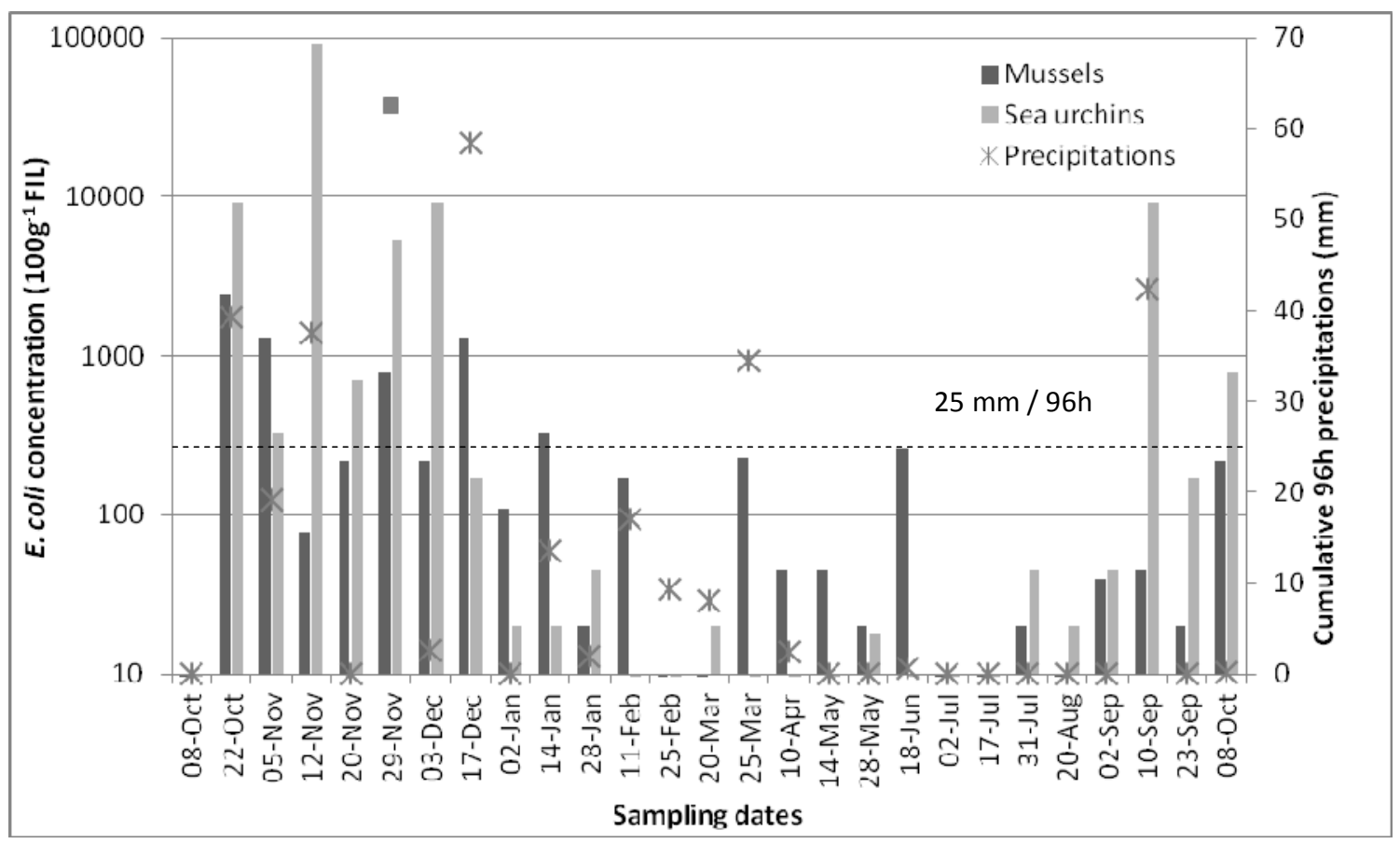

This article is protected by copyright. All rights reserved. 
Figure 2: Map of the sampling area

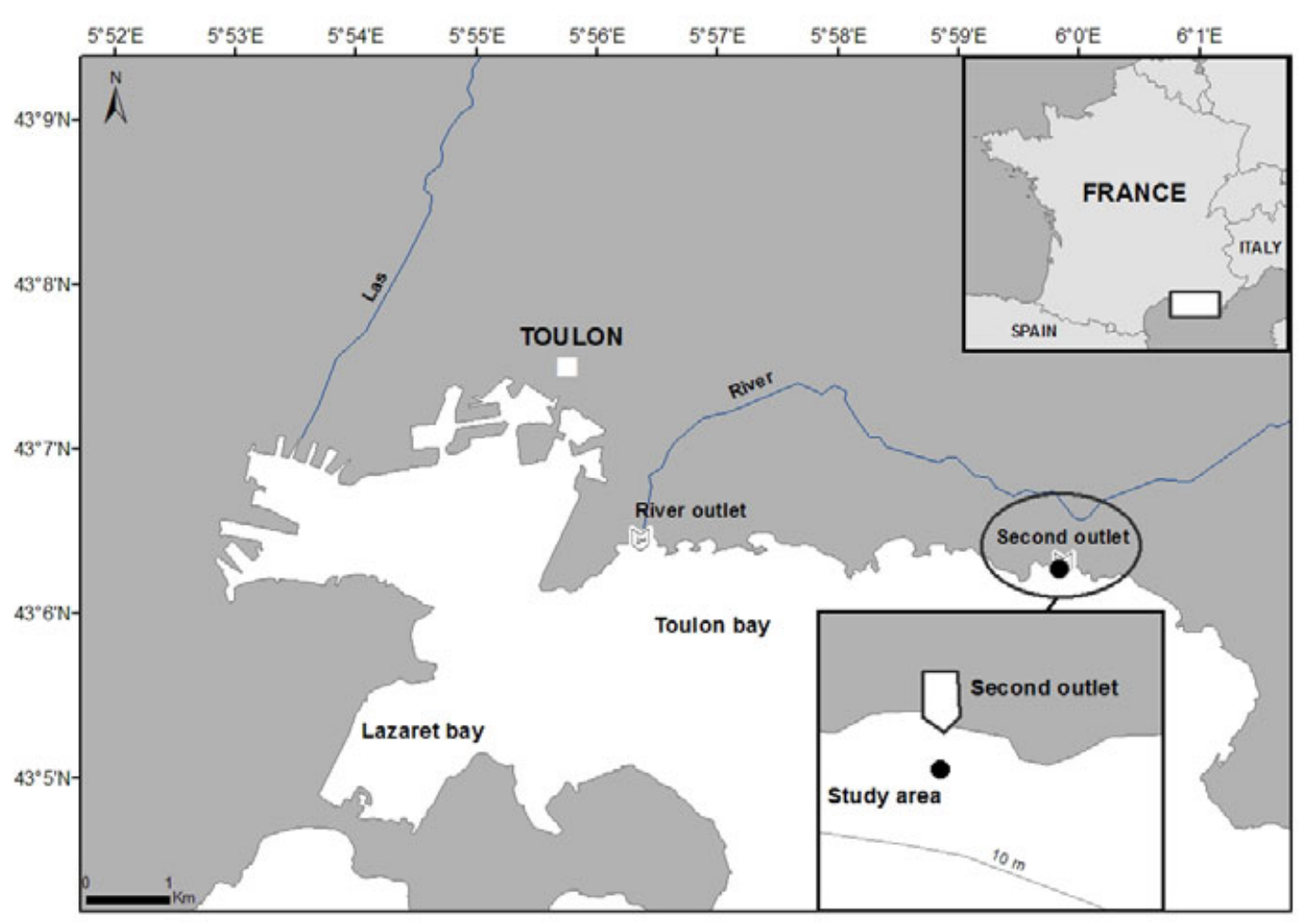

This article is protected by copyright. All rights reserved. 
Table 1: Number and percentage of mussel and sea urchin samples containing various concentrations of $E$. coli when classified according to regulation (EC) No 854/2004 (Anon. 2004). The descriptive statistics are provided for samples that were routinely collected, collected during rainfall events, and for the whole dataset. Maximum E. coli concentrations (Max) and geometric means are also reported.

\begin{tabular}{|c|c|c|c|c|c|c|c|c|c|}
\hline & & & & & & coli $100 \mathrm{~g}^{-1}$ FIL & & & \\
\hline Dataset & Species & $N$ & $<230$ & [230- 1000[ & {$[1000-4600[$} & [4 $600-46000[$ & $\geq 46000$ & Max & $\begin{array}{c}\text { Geometric } \\
\text { mean }\end{array}$ \\
\hline Regular & Sea urchins & 21 & $16(76 \%)$ & $4(20 \%)$ & 0 & $1(4 \%)$ & 0 & 9200 & 51 \\
\hline monitoring & Mussels & 21 & $18(86 \%)$ & $2(10 \%)$ & $1(4 \%)$ & 0 & 0 & 1300 & 58 \\
\hline Heavy rainfall & Sea urchins & 6 & 2 (33\%) & 0 & 0 & $3(50 \%)$ & $1(17 \%)$ & 92000 & 2247 \\
\hline periods & Mussels & 6 & $2(33 \%)$ & $2(33 \%)$ & $2(33 \%)$ & 0 & 0 & 2400 & 355 \\
\hline 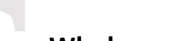 & Sea urchins & 27 & 19 (70\%) & 3 (11\%) & 0 & $4(15 \%)$ & $1(4 \%)$ & 92000 & 119 \\
\hline & Mussels & 27 & $20(74 \%)$ & $4(15 \%)$ & $3(11 \%)$ & 0 & 0 & 2400 & 86 \\
\hline
\end{tabular}

This article is protected by copyright. All rights reserved. 